Click www.researchjournal.co.in/online/subdetail.html to purchase.

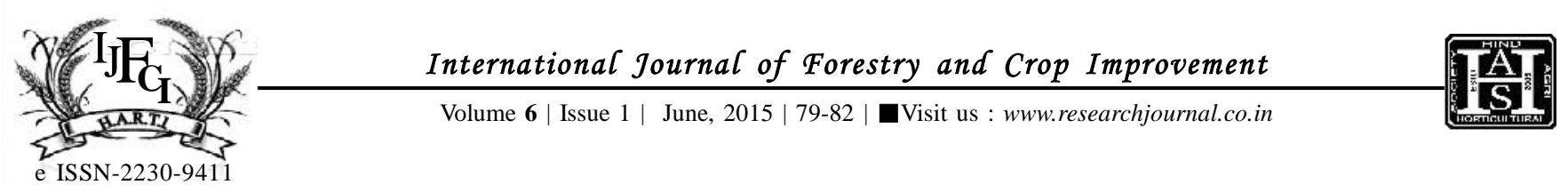

A REVIEW

DOI: $10.15740 / \mathrm{HAS} / \mathrm{IJFCI} / 6.1 / 79-82$

\title{
Pride of India [Lagerstroemia speciosa (L.) Pers.] forming a silver bullet for $\mathbf{2 1}^{\text {st }}$ century
}

\author{
MOHINI UTTAM DHAKANE AND S.G. YADAV
}

KEY WORDS : Silver bullet, Pride of India, Lagerstroemia speciosa

How TO CITE THIS ARTICLE : Dhakane, Mohini Uttam and Yadav, S.G. (2015). Pride of India [Lagerstroemia speciosa (L.) Pers.] forming a silver bullet for $21^{\text {st }}$ century. Internat. J. Forestry \& Crop Improv., 6 (1) : 79-82.

Article ChronicAL : Received : 04.09.2014;Accepted : 16.05.2015

\section{INTRODUCTION}

Lagerstroemia speciosa awarded as 'Pride of India' propounds a wide spectrum of popularity due to its attractive and scenic prettiness. Its pleasant beauty accompanied by a spectacular blooming makes it highlighted as 'Queen among the flowers'. Locally it is known as a 'Jarul' in Hindi, 'Taman' in Marathi, 'Kramuka' in Sanskrit, 'Kadali' in Tamil Nadu, 'Banaba' in Oriya and 'Queen Crape Myrtle' for trade purpose (Gilman and Watson, 1993). It is well known member of 'Lythraceae' tracing origin to 'Tropical Southern Asia' (Ellis et al., 2007).

\section{Ornamental characteristics of Lagerstroemia speciosa:}

Morphological features especially their flowers blessed with lavender, pink, purple, red and white 6-10

\section{MEMBERS OF RESEARCH FORUM}

Address of the Correspondence : MOHINI UTTAM DHAKANE, School of Forestry and Environmental Science, Sam Higginbottom Institute of Agriculture, Technology and Sciences, ALLAHABAD (U.P.) INDIA Email: mohinidhakane@gmail.co.in

Address of the Coopted Authors : S.G. YADAV, Department of Botany, Shivaji Mahavidyala (SRTMU), Renapur, LATUR (M.S.) INDIA inches cluster bloom with ruffled and crinkly appearance. Generally, it flowers in spring but summer flowering is showy. The upright spreading, vase-shaped stunning canopy distribution, bark surface with papery flakes, goudy trunk and light buttressed formation formulates banaba as center of allurement. It ameliorates road side-avenue plantation, gardens, landscapes, parking lots and homesteads. Beside its cosmic adorning potential, it offers a huge scope of multipurpose benefits. This article tries to compile the ornamental character along with invaluable biological and chemical prospective which would serve as 'silver bullet' of ever increasing inhabitants.

\section{Multipurpose benefits obtain from banaba :}

Lagerstroemia speciosa exhibits moderately hard timber properties thus, consistently utilized for making decorative furniture, agriculture implements, ploughs, boats, posts, rafts and beams. Their capsular fruits make it suitable for interior decoration (Pandey, 2012). Powdered leaves form a reagent for coloring hairs (Gilman and Watson, 1993). Pruned branches can be composted and used as qualitative biofertilizer (Sannigorahi, 2009). Being a fodder component, it shows a positive attributes (Chhetri, 2010). Presently, rearing 